\title{
Biogeography and Population Connectivity of Coral Reef Fishes
}

\author{
Rachel A. Morrison and Stuart A. Sandin \\ Scripps Institution of Oceanography, University of California, San Diego \\ USA
}

\section{Introduction}

Most fundamentally, the distribution of populations and species is a function of both habitat availability and dispersal ability. Understanding the patterns that result from the interaction of these factors is one of the central aims of ecology. It has long been recognized that populations are not evenly distributed throughout the entire geographic range of the species. Populations occupy spatially distinct patches of suitable habitat that are separated from each other by areas of unsuitable habitat. Depending on factors such as the distance between populations, the nature of the intervening environment, and the relative mobility of the organisms in question, areas of unfavorable habitat may or may not prevent movement of individuals among patches. Given a long enough period of isolation between populations of the same species, speciation or local extinction may result. The degree of connectivity among populations therefore has major ecological and evolutionary implications.

Though the implications of connectivity have long been acknowledged and explored in terrestrial organisms, variable connectivity patterns are only beginning to be recognized as an important driver of present-day population dynamics in the marine realm. It had long been assumed that, due to the lack of visible barriers and the presumed ability of larvae to passively disperse great distances by riding ocean currents, marine organisms dispersed freely and had high levels of population connectivity throughout their ranges. Recent studies in coastal habitats, however, have revealed that the larvae of many coral reef fish species actually settle much closer to their natal reefs than previously thought (Almany et al., 2007; Jones et al., 1999; Kingsford et al., 2002; Planes et al., 2001, Swearer et al., 1999; Taylor \& Hellberg, 2003). Similarly, population structure has been found in pelagic species such as cod (Bentzen et al., 1996; Ruzzante et al., 2000) and tuna (Block et al., 2005; Carlsson et al., 2004).

The existence of patchy marine populations, especially if the patches are not connected by migration or dispersal, has enormous implications for biodiversity conservation and management. For instance, isolated populations are more prone to extinction than are more connected ones (Munday, 2004). In this chapter we present an overview of the distribution and population connectivity patterns of coral reef fishes and the methods that have been used to quantify them. We argue that widespread variability in predicted and observed patterns can be explained via the interaction between reef fish life history traits and oceanographic conditions. We emphasize throughout the importance of understanding the 
interactions among evolutionary, ecological, and physical processes in structuring contemporary distribution and dispersal patterns. Finally, we address how a better knowledge of connectivity among reef fish populations holds the potential to dramatically improve management and conservation of threatened coral reef ecosystems.

\section{Coral reef fish biogeography: The link between evolutionary and ecological processes}

Biogeography, or the study of the distribution of organisms in space and time, asks which species occur where, and why or why not (MacArthur and Wilson, 1967). The answers to these questions are complex, since contemporary distribution patterns of organisms reflect biological and physical processes operating at multiple spatial scales, on both evolutionary and ecological time scales. We focus here on the study of coral reef fishes, specifically the ten families that are considered to be characteristic of modern coral reef ecosystems: Acanthuridae (surgeonfish), Apogonidae (cardinalfish), Bleniidae (blennies), Carangidae (jacks), Chaetodontidae (butterflyfish), Holocentridae (squirrelfish), Labridae (wrasses), Mullidae (goatfish), Pomacentridae (damselfish and clownfish), and Scaridae (parrotfish) (Bellwood, 1996). Coral reefs have existed in some form since the Ordovician period (Wood, 1999), and the biogeographic and taxonomic patterns observed in coral reef fish families today reflect a long and complex history of geological, oceanographic, and biological interactions (Bellwood \& Wainwright, 2002). The contemporary distribution and population structure of coral reef fishes appear to be similarly mediated by both geography and life history. In our subsequent discussion of emergent biogeographic and taxonomic patterns, we use the term "reef fish" to refer specifically to tropical coral reef fish.

\subsection{Temperature controls the distribution of suitable habitat}

The global dispersal of coral reef fishes is broadly controlled by the availability of suitable habitat, which is dictated by the shape of the latitudinal temperature zone around the Equator. The Tropical Zone (Figure 1) was formed by dramatic cooling at high latitudes long ago in the Earth's geological history, and it remains constrained today by the flow of major ocean currents (Briggs, 2007). Oceanography also influences reef fish distributions within the confines of this tropical zone. On the western sides of the Atlantic and Pacific Ocean basins, the North and South Equatorial currents turn toward higher latitudes, bringing warm water and tropical organisms with them. On the eastern sides of the ocean basins, however, the major currents turn toward the tropics, transporting colder water from higher latitudes toward the Equator. This oceanographic pattern ensures that the western regions of each basin have a larger area of tropical marine habitat (Briggs, 2007), and therefore greater species diversity, than do the eastern regions.

The Tropical Zone (TR) defines the latitudinal availability of suitable tropical habitat. Within this temperature zone, several major faunal boundaries have contributed to marine speciation events in the past and continue to act as barriers to reef fish dispersal in the present: the Red Sea land bridge, the Indo-Pacific Barrier, the Eastern Pacific Barrier, and the Isthmus of Panama. Together with temperature restrictions, these dispersal barriers have produced five longitudinal biogeographic regions: the Indian Ocean, the Indo-West Pacific, the Eastern Pacific, the Western Atlantic, and the Eastern Atlantic (Bellwood \& Wainwright, 2002; Briggs, 2007). 


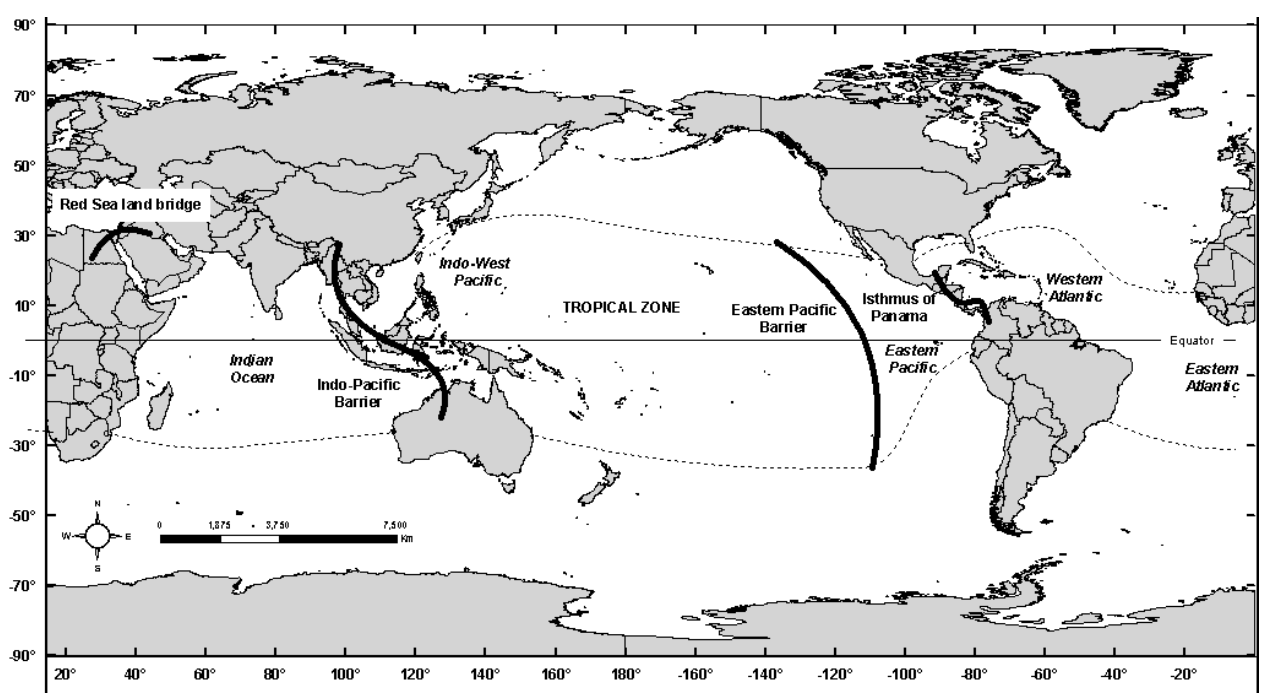

Fig. 1. Major physical factors affecting the global distribution of reef fishes, and resulting biogeographic regions.

Despite these divisions, there is broad taxonomic overlap of reef-associated fishes worldwide. Of the ten families that are considered to be characteristic of coral reef systems (Bellwood, 1996), few are restricted to only one region, and in most cases overlap is extensive at the genus level (Briggs, 1974). The Western Atlantic region, with 700 species of fish (Rocha, 2003), is essentially a more species-poor version of the tropical Pacific, which hosts more than 4000 fish species (Springer, 1982). The reef fish fauna of the Western Atlantic and the Eastern Pacific biogeographic regions are very similar, probably reflecting their connection prior to the closure of the Isthmus of Panama (Bellwood \& Wainwright, 2002).

\subsection{Historical barriers to dispersal}

Over evolutionary history, geological processes have created a series of environmental barriers to dispersal that progressively separated reef fish taxa among the ocean basins. Cooling at high latitudes "locked in" the tropics 37 million years ago, restricting the movement of tropical species to a latitudinal band around the Equator now known as the Tropical Zone (Briggs, 2007). Later, the Atlantic and Indian oceans were cut off from each other when Africa collided with Eurasia 12-18 million years ago, and the uplift of the Isthmus of Panama around 5 million years ago separated the Atlantic from the Pacific. The last tropical connection between the ocean basins was effectively closed 2 million years ago by the formation of the Benguela upwelling, a cold-water barrier, off the Atlantic coast of southern Africa (Bellwood \& Wainwright, 2002). These and other historical barriers to dispersal (Figure 1) prevented the exchange of individuals among populations, causing both extinctions and speciation events (Bellwood \& Wainwright, 2002; Palumbi, 1994).

Biogeographic barriers that resulted in historical vicariance events can continue to hinder dispersal among populations. For instance, the Pacific has been divided into three major biogeographic regions: the Indian Ocean, the Indo-West Pacific, and the Eastern Pacific. The 
barriers between these provinces include the world's largest uninterrupted expanse of deep ocean, the 4000 - $7000 \mathrm{~km}$ wide Eastern Pacific Barrier, which isolates the Eastern Pacific from the rest of the Pacific, and the Indo-Pacific Barrier, the dense mass of islands and continents (including Australia) that separates the Indian and Pacific Oceans (Figure 1). The latter barrier is enhanced during low sea level stands, when there are fewer passages between islands, and by strong upwelling that is likely to reduce the habitat available for tropical species (Barber et al., 2002).

\subsection{How biogeography helps us to understand population connectivity}

The present-day distribution of coral reef fishes is heavily influenced by physical and geological events in the history of the earth that defined the boundaries of the tropical region and the various ocean basins. In addition to the evolutionary-scale processes that have structured the distribution of tropical marine species, ecological processes act to maintain current distribution patterns (Bellwood \& Wainwright, 2002). For instance, the scale of dispersal of reef fishes influence how populations within a species are spatially distributed (James et al., 2002). Due to the lack of visible obstructions in the marine realm and the presumed ability of larvae to passively disperse great distances, the prevailing paradigm for decades was that marine fish populations mixed freely and had high levels of connectivity throughout their ranges. In other words, the popular view was that marine populations were largely open, connected by demographically significant movement of individuals (immigration and emigration) (Hixon et al., 2002).

Biogeography tells us that species are not uniformly distributed throughout their ranges, and it is obvious that the long-held belief in freely dispersing marine populations discounts temporal and spatial variability in environmental conditions and dispersal patterns among sites. It became apparent only recently that barriers to dispersal, aside from delimiting distribution patterns in evolutionary time, could also structure populations of marine species on ecological time scales. The assumption of range-wide population openness has been challenged by a litany of recent studies showing that coral reef fish larvae, even of widely distributed species, often settle closer to their natal reefs than previously thought (Almany et al., 2007; Jones et al., 1999; Jones et al., 2005; Kingsford et al., 2002; Leis, 2002; Planes et al., 1998; Planes et al., 2001, Swearer et al., 1999; Taylor \& Hellberg, 2003).

The nature of connectivity has important ecological and evolutionary implications. At one extreme, if reef fish populations are highly connected among patches, they may be more able to withstand local disturbances that degrade or remove habitat, and in the long term they may be less prone to local extinction. Under such open population models, we may expect only slow rates of evolution due to the very large effective population sizes. At the other extreme, if populations are isolated from one another, they may be more prone to local extinction as a result of habitat degradation or loss, since they are not supplemented by immigration of individuals from elsewhere. Further, over long periods of time genetic differences may build up such that reef fish populations become reproductively isolated, with the capacity to form new species.

The influence of connectivity on speciation is particularly relevant when discussing how historical context informs present-day population connectivity in reef fishes. Within the five major biogeographic regions of the tropics (the Indo-West Pacific, the Eastern Pacific, the Western Atlantic, the Eastern Atlantic, and the Indian Ocean), reef fish species are not evenly distributed. Rather, they have become concentrated into relatively small areas of 
very high biodiversity. The Coral Triangle (also known as the East Indies Triangle) and the southern Caribbean are centers of diversity for the Indo-West Pacific and Western Atlantic regions, respectively. In the biogeographic provinces of the Coral Triangle and the southern Caribbean, at least $10 \%$ of the fauna are endemic species (Briggs, 1974). In the Coral Triangle in particular, speciation rates are so remarkable that Mora et al. (2003) observed that there seemed to be a continuous flow of species from the East Indies outward across the Indian and Pacific oceans.

Why are these particular areas of the tropics, specifically the Coral Triangle, effectively functioning as species factories? It is known that scales of dispersal influence speciation rates (Palumbi, 1994). Multiple, smaller scale barriers to gene flow clearly operate within the larger biogeographic regions, isolating populations by preventing dispersal among them. Barriers to dispersal that create population divisions within species on an ecological scale will become evolutionary-scale if they persist and lead to speciation or extinction. Biogeographical patterns of species distributions therefore simply reflect population structure that has been reinforced over evolutionary time. Indeed, studies are increasingly revealing that, even without obvious barriers to dispersal, populations of species that are morphologically alike are often divergent enough to be considered separate, or sibling, species (Knowlton, 1993).

The recognition that marine populations are not uniformly well mixed throughout their ranges has fundamentally changed the way biologists and ecologists think about the distribution of marine species, especially coral reef fishes. It is no longer enough to recognize habitat patchiness as a driver of population dynamics. We are now compelled to evaluate the scale of patchiness, or the relative openness, of each marine population in question, which may or may not correlate with the availability of suitable habitat. In other words, the question has become about the temporal and spatial scales of mixing among populations. Quantifying this connectivity is crucial for understanding local adaptation and speciation, population replenishment, and the likelihood of local extinction. While there are still examples of populations that appear to be highly open (Eble et al., 2011) as well as highly closed (Jones et al., 2005), the majority of reef fish populations likely lie somewhere along a continuum, and the important task going forward will be identifying where different organisms occur along this spectrum.

\section{Quantifying connectivity by estimating larval dispersal}

Despite its critical ecological importance, population connectivity remains notoriously difficult to quantify directly. Most coral reef fishes have a biphasic life cycle with a dispersive larval phase and a relatively less mobile adult phase. Movement from one site to another is thus accomplished mainly via larval dispersal, as opposed to adult migration. The pelagic stage of reef fishes is critical for connecting populations among patchy habitats but is arguably the least understood phase of their life cycle (Planes, 2002). In particular, the smallness of larvae relative to their vast and complex fluid environment (Mora \& Sale, 2002) has hindered accurate quantification of dispersal and connectivity.

Both direct and indirect attempts have been made to measure larval dispersal. For decades, a popular method of tracking taxa such as whales (Ray et al., 1978) and tuna (Fink and Bayliff, 1970) has been tagging, in which a satellite or radio tag is physically attached to or implanted into the animal. These tags potentially yield a detailed record of movement over time. For obvious reasons, this approach is not possible with reef fish larvae, but another form of tagging has been attempted. A mark-recapture method has been developed that 
involves tagging the otoliths of larval fishes by saturating the surrounding water with a chemical, such as tetracycline, that becomes incorporated into the calcium carbonate structure of the otolith (Jones et al., 2005; Thorrold et al., 2002). Later analyses of juvenile fish otoliths reveal the chemical signature. Such methods, however, are often prohibitively time-consuming and expensive, with low returns due to extensive larval mortality and dilution in the ocean. For instance, Jones et al. (1999) tagged over 10 million developing embryos of a damselfish (Pomacentris amboinensis) on the Great Barrier Reef in Australia. Of 5,000 juveniles subsequently settling at the same location, the authors retrieved 15 marked individuals (Jones et al., 1999), a return rate of just $0.00005 \%$.

The many difficulties associated with direct tracking of larvae have encouraged the development of indirect, more efficient methods of estimating larval dispersal. Monitoring ocean currents is a relatively straightforward way to predict larval dispersal and adult migration (Cowen, 2002; Cowen et al., 2000; Lobel, 1997), but a major handicap of this approach is that it relies on the assumption that larvae drift passively with currents, which is not always true (Gerlach et al., 2007; Kingsford et al., 2002). In addition, long-term mean current patterns may differ from local or infrequent oceanographic conditions that could affect dispersal.

\subsection{Genetics: From phylogeography to molecular ecology}

It was first suggested in 1975 that genetic variation could be the best approach for assessing dispersal and migration among geographically separated populations of reef fishes (Ehrlich, 1975). In tandem with advances in the field of molecular ecology, in the past several decades the analysis of genetic information has emerged as a means to understand the distribution and diversity of marine species and populations (Bohonak, 1999; Burton, 1996, 2009; Grosberg and Cunningham, 2001; Hellberg et al., 2002; Shulman, 1998; Slatkin, 1987). This indirect method is possible because the dispersal of propagules maintains gene flow between geographically separated populations (Hellberg et al., 2002; Shanks et al., 2003). Genetics-based methods can infer gene flow, and therefore dispersal, through spatial variation in allele and genotype frequencies (Hedgecock et al., 2007; Planes, 2002). Therefore, the same factors that influence dispersal, or larval "flow", can be assumed to also influence gene flow (but see Section 3.2 for a discussion of caveats to this assumption).

On evolutionary time scales, the study of phylogeography assesses genetic diversity among species to examine historical processes that may be responsible for contemporary geographic distributions (Rocha et al., 2007). Phylogeographic approaches rely on genetic markers that reflect deep historical linkages among taxa in order to build gene genealogies, or trees, that help to explain contemporary species-level relationships. For instance, the Barcode of Life is a recent initiative to catalog diversity based on a region of the genome that varies in an easily identifiable, species-specific manner (Hebert et al., 2003).

Because biogeographic and ecological processes are linked, genetic information can also be used to evaluate whether connections exist among spatially segregated populations of the same species (Shulman \& Bermingham, 1995); that is, are populations demographically open or closed (Mora \& Sale, 2002) on ecological time scales? In theory, predictable recruitment and connectivity patterns are expected to drive stable genetic structure among populations (Purcell et al., 2006). If larvae are dispersed randomly and widely away from the parental populations, then no consistent genetic structure will occur. On the other hand, if larvae are returned to the parental population, then gene flow between geographically 
separated populations will be restricted, and genetic structure will arise (Shulman \& Bermingham, 1995).

Several well-known theoretical models of population genetic structure have existed since well before the application of genetic information to estimating larval dispersal. These models describe expected patterns of structure, given a certain set of conditions. For instance, the so-called isolation by distance pattern can arise in species with sufficiently large geographic ranges relative to their dispersal ability. Wright (1943) introduced this model to describe how genetic differences could accumulate over time, given restricted dispersal. In conjunction with the stepping-stone model of population structure (Kimura and Weiss, 1964), the isolation by distance model has developed to describe the population structure among organisms whose dispersal ability is constrained by distance, such that gene flow is most likely to occur between neighboring populations (Slatkin, 1993). Together, these approaches link gene flow with geographic distance (Planes and Fauvelot, 2002).

Predicting the population genetic structure that may result from a given pattern of larval dispersal, however, is not so straightforward, as there are many influences on dispersal besides geographic distance. It is important to explicitly consider all of the factors that influence dispersal, and therefore gene flow. Certain life history and behavioral traits, oceanographic conditions, and historical barriers to dispersal all influence whether geographically disjunct populations of coral reef fishes are connected via planktonic larval dispersal.

The variation in the magnitude of observed genetic structure may depend critically on the life history of the study species (Gerlach et al., 2007), such as the timing and location of spawning relative to currents, gyres, and tides (Pelc et al., 2009). Egg type and reproductive strategy also play a role (Leis \& McCormick, 2002). The pattern of high gene flow for reef fish with a pelagic larval phase is supported by numerous examples of reef fishes that show no significant population structure over distances spanning thousands of kilometers (Craig et al., 2007; Horne et al., 2008; Klanten et al., 2007; Palumbi, 1994; Planes \& Fauvelot, 2002; Riginos and Victor, 2001). Species with non-pelagic larvae such as clownfish and damselfish, meanwhile, tend to show strong genetic structure indicative of high levels of local recruitment (Jones et al., 1999). In a study of gene flow in eight reef fish species, Shulman \& Bermingham (1995) found no evidence of genetic structure across the Caribbean except in species that lacked pelagic larvae.

The length of time that larvae spend in the water column has also been implicated as a factor affecting dispersal and genetic structure (Bowen et al., 2006; Weersing \& Toonen, 2009). Reef fishes typically have larval lives lasting for weeks or months, seemingly long enough to achieve dispersal great distances away from the source population. It seems intuitive that the longer a larval propagule stays in the water column, the farther it will travel. However, there is no consistent correlation between pelagic larval duration (PLD) and geographic range size (Lester et al., 2007; Lester \& Ruttenberg, 2005; Victor \& Wellington, 2000), or between PLD and population genetic structure (Weersing \& Toonen, 2009). Previously reported correlations appear to have been driven by species lacking a pelagic larval phase (Eble et al., 2011). Reproductive strategy may thus be a stronger influence than PLD on dispersal. Larvae can also actively participate in their own dispersal through evolved behaviors such as "smelling home" (Gerlach et al., 2007) and navigating toward sensed targets, which in sum can promote local retention.

Superimposed on the patterns of variable life history traits is the larger pattern of abiotic influences on dispersal, including oceanographic features such as currents, eddies, tides, 
and fronts (Cowen, 2002). It is well known that larvae of marine species can accumulate at fronts (Roughgarden et al., 1991). Regional currents, as well as secondary or indirect currents, are also important (Visram et al., 2010). As our understanding of ocean physics improves, the role of advection and diffusion in larval dispersal is also beginning to be appreciated (Largier, 2003). Points, jets, and retention zones can cause variable larval transport along coastlines (Gaylord and Gaines, 2000; Largier, 2004; Richards et al., 1995). Seasonal shifts in current patterns and episodic events such as relaxation of upwelling (Largier, 2004) may have significant consequences for larval transport and recruitment. At large scales (greater than $300 \mathrm{~km}$ ), studies have linked areas of strong genetic structure in fishes and corals to major oceanographic and environmental features (Baums et al., 2006; Galarza et al., 2009; Galindo et al., 2006; Pelc et al., 2009).

Finally, studies have shown that even marine species with high dispersal potential break into genetically similar groups within biogeographic provinces (soldierfish, Craig et al., 2007; surgeonfish, Planes and Fauvelot, 2002). For instance, Barber et al. (2000) observed a sharp, localized genetic break among stomatopod populations in Indonesia, suggesting a marine counterpart to the Wallace's line that separates terrestrial fauna there. These results demonstrate that biogeographic provinces that were formed millions of years ago can still function as barriers to dispersal today, even in widely ranging species (Barber et al., 2000).

\subsection{The double-edged sword of molecular ecology}

Predicting patterns of genetic structure is inherently difficult, and empirical measurements often fail to correspond to predictions. In the Pacific, biogeographic divisions do not appear to affect the dispersal of some reef fish species, possibly due to the extensive mixing and unstable circulation generated by El Niño events and other phenomena (Muss et al., 2001). Limited genetic subdivision across reefs of the Pacific has been demonstrated in a number of reef fishes, such as surgeonfish (DiBattista et al., 2011; Eble et al., 2011; Horne et al. 2008; Klanten et al., 2007), grouper (Rivera et al., 2011), parrotfish (Bay et al., 2003), snapper (Evans et al., 2010), and angelfish (Schultz et al., 2007). Some species have been shown to traverse even biogeographic barriers that were thought to be insurmountable, such as the Eastern Pacific Barrier (Lessios \& Robertson, 2006; Figure 1). Conversely, sometimes population genetic structure is observed despite an apparent lack of barriers to dispersal (Planes et al., 1998; Taylor and Hellberg, 2003; Toonen et al., 2011).

These discrepancies have several possible explanations related to the power of genetic analyses to resolve ecologically meaningful patterns. If genetic structure is present, but weak, then deciding whether populations are open or closed at the scale in question can be difficult (Hepburn et al., 2009). Moreover, though some of the factors producing population genetic structure are intimately related to demographic processes, others are not. Though it is commonly assumed that genetic structure reflects a balance between gene flow and genetic drift, migration and dispersal are not the only influences on genetic differentiation. Other forces such as natural selection and historical contact between populations can influence the allele frequencies used to evaluate levels of dispersal (Bohonak, 1999; Planes, 2002). For instance, even if gene flow is occurring, natural selection can be a major force maintaining genetic differentiation among populations (Mora \& Sale, 2002). Patterns over evolutionary time (natural selection and historical contact) can therefore influence the genetic structure observed in ecological time, and this is cause for caution when interpreting 
genetic data as a reflection of demographic patterns. Furthermore, because an exchange of just one individual per generation can result in genetic homogeneity (Planes, 2002), populations may be linked genetically without an obvious demographic connection (Kool et al., 2010). When interpreting genetic patterns in the context of ecology, then, it is critical to discriminate based on temporal scale, delineating evolutionary versus ecological connectivity.

Adding complexity to studies of connectivity is selecting genetic markers, a process that is rife with controversy even within the molecular ecology community (Fauvelot et al., 2007; Hellberg, 2007, 2009). Because different markers have different spatial and temporal powers of resolution, great care must be taken in both selecting markers and interpreting patterns of genetic structure obtained from analyses of variation in those markers. Two types of markers that are commonly used in genetic studies, allozymes and mitochondrial DNA (mtDNA), are not very sensitive to genetic drift at the appropriately short temporal scales (Hellberg, 2009). These types of markers are useful for evaluating the evolutionary relationships of closely related populations and for inferring connectivity over longer temporal scales. Demographic studies, on the other hand, require that markers are able to drift distinctively among populations at temporal scales that are relevant to population replenishment. For these types of studies, other DNA markers called microsatellites are promising alternatives to the more traditionally used allozymes and mtDNA. Microsatellites are gaining popularity among molecular ecologists because they have a high mutation rate and are probably neutral to selection (Hellberg, 2009). Their mutation rate is high enough to result in a large amount of variation among unrelated individuals within a population, but low enough so that changes usually do not occur more often than every few generations (Hartwell et al., 2008). Microsatellites can therefore detect subtle differentiation among closely related individuals, which is useful for determining ecologically relevant connectivity as opposed to more historical population subdivisions (Hellberg, 2009). Ideally, to begin to address these differences, population connectivity studies should at least compare results obtained from multiple markers.

Finally, different methods of characterizing genetic structure and estimating gene flow make different assumptions about the equilibrium status of populations, migration patterns, population structure, and the attributes of genetic markers (Grosberg \& Cunningham, 2001). Sampling protocols are widely variable, as are geographic and temporal scales surveyed. In addition to the inherent limitations of using population genetic structure to infer dispersal, this lack of a cohesive approach further complicates the interpretation of genetic structure analyses.

There are several ways to counteract the pitfalls inherent in a molecular ecology approach. More direct genetic methods for tracking larvae, such as parentage analysis (Christie et al., 2010; Jones et al., 2005; Planes et al., 2009; Saenz-Agudelo et al., 2009), are gaining traction, but this approach is really only feasible with strongly site-attached taxa such as clownfish, where brooded larvae can be easily associated with a parental source. Other recent genetic advances include the ability to resolve the high temporal variation in reproduction and recruitment patterns that commonly occurs among Caribbean and Pacific reef fishes (Sale et al., 2005). At small scales, this temporal variation produces a complex pattern called chaotic genetic patchiness (Johnson \& Black, 1982), which remained unexplained until recently (Selkoe et al., 2010). It is important to detect the causes of this variability, as spatial and temporal variation in connectivity may itself help to promote long-term stability in populations (Hogan et al., 2010). 


\subsection{Integrating multiple types of data: An example from the Caribbean}

There is a growing recognition that, given the complexity of larval dispersal, genetic data are most useful when analyzed in tandem with models, oceanographic data, or other approaches (Galindo et al., 2006; Rivera et al., 2011; Selkoe et al., 2008). In the absence of inexpensive, effective methods of directly measuring larval dispersal, such integrated approaches represent the next best strategy to obtain ecologically meaningful data, as emphasized in the following example from the Caribbean.

The Caribbean is an essentially closed ocean basin with relatively stable current systems since the shoaling of the Isthmus of Panama around three million years ago (Briggs, 2007). The basin is biogeographically isolated from the southwestern tropical Atlantic (e.g., Brazil) by the inter-regional barrier of the Amazon outflow, and from the eastern tropical Atlantic (e.g., western Africa) by sheer distance (Floeter et al., 2008). Within the Caribbean, species distribution patterns suggest that there are few biogeographic divides for reef fish, with most species ranges spanning the entire basin. As such, species richness across Caribbean islands is predicted best by island size and distance from neighbors, rather than by taxonspecific dispersal histories (Sandin et al., 2008). The biogeography and oceanography of the Caribbean would seem to indicate a strong potential for population connectivity, and therefore genetic similarity, across the basin. Given its stepping-stone geography and a total distance along a current track of $4500 \mathrm{~km}$, Shulman \& Bermingham (1995) suggested that it could take as few as 13 generations for a novel haplotype to spread throughout the basin. Correspondingly, studies have shown high rates of gene flow in reef fish leading to genetic similarity within taxa throughout the Caribbean (Lacson, 1992; Shulman \& Bermingham, 1995).

In contrast, a model by Kool et al. (2010) showed that, while reef fish populations in the Caribbean became increasingly genetically connected with one another over time, relative differences between populations persisted, providing the basis for the development of genetic structure. Similarly, a biophysical model by Cowen et al. (2006) identified four broadly defined, distinct regions of population isolation: the eastern Caribbean, the western Caribbean, the Bahamas-Turks and Caicos Islands, and the region at the periphery of the Panama-Colombia gyre. These regions correspond to genetic and morphological clines observed across a range of marine organisms (Cowen et al., 2006). Given the significant degree of structure expected to be present in the Caribbean from these model simulations (Cowen et al., 2006; Kool et al., 2010), why are strong breaks between populations not more evident in observations of natural populations (Purcell et al., 2006; Shulman \& Bermingham, 1995)? This discrepancy may occur because sampling a limited number of individuals decreases the amount of visible structure (Kool et al., 2010). That empirical studies may be inherently limited by sampling power relative to model simulations is therefore an important consideration in evaluating results of population genetic studies.

\section{How do we account for this variability? A model of passive and active dispersal}

When considering the pronounced variation in the biotic and abiotic factors determining dispersal, it is unsurprising that published estimates of connectivity and dispersal in coral reef fishes vary widely (Cowen et al., 2006; Purcell et al., 2006; Gerlach et al., 2007; Hepburn et al., 2009) and that no general relationship between spatial scale and the likelihood of populationlevel genetic divergence has emerged (Hepburn et al., 2009). Given the complexities and simplifying assumptions involved in equating gene flow with dispersal, this variability is 
partly a relic of the genetics methods used to estimate dispersal. The majority of marine species have high rates of gene flow over evolutionary time scales (Hedgecock et al., 2007). Determining the extent to which populations are connected on an ecological scale, despite high gene flow at an evolutionary scale, remains the single greatest challenge for revealing ecologically meaningful patterns of larval dispersal (Botsford et al., 2009).

The case study from the Caribbean illustrates this dichotomy between evolutionary gene flow and ecologically relevant dispersal. Even though studies have shown genetic similarity across the Caribbean, suggesting basin-scale mixing among reef fish populations (Geertjes et al., 2004; Lacson, 1992; Shulman \& Bermingham, 1995), the ecologically meaningful pattern of larval dispersal is likely at the regional scale (Cowen et al., 2006). Isolation in reef fish populations at this scale has also been shown in other oceanographically and geographically complex regions such as the Indo-Pacific (Drew et al., 2008).

The paradigm shift in marine population connectivity means that, on ecological time scales, reef fish populations are now considered to be substantially closed, rather than broadly open (Mora \& Sale, 2002). Effective dispersal is much smaller than potential dispersal extrapolated from ocean current speed and pelagic larval duration (Planes, 2002). We may therefore expect a relatively narrow dispersal kernel for most species, with most offspring settling near to the location where they were produced (Figure 2). This pattern of enhanced local retention (Roberts, 1997) can be explained by active, as opposed to passive, mechanisms limiting the distances that most offspring disperse. Reef fish can employ a suite of spatial, temporal, and behavioral adaptations that interact with local oceanographic conditions to enhance local retention of larvae (Kingsford et al., 2002; Sponaugle et al., 2002; Figure 2).

In the passive model, larval density is best approximated as a normal distribution generated by a random-walk model of movement away from natal reef. Local retention of larvae is fairly evenly balanced with widespread dispersal. This pattern is produced if adult fishes do not spawn preferentially near ocean currents that would keep larvae close to shore, if spawning occurs regardless of lunar phase, and if larvae drift passively with ocean currents once spawned. In the active model, however, local retention of larvae is enhanced, and widespread dispersal is substantially reduced (to about $10 \%$ of offspring). This pattern can arise from spawning aggregations near ocean currents that retain larvae near the coast (Lobel, 1989), from spawning timed to a particular lunar phase, and from active swimming behaviors of larvae that allow them to respond to stimuli from their natal reef (Gerlach et al., 2007). It can be difficult to resolve the spatial and temporal scales at which each factor is most important, but this is critical to understanding marine population connectivity, since the interaction of life history and oceanography produces an emergent pattern that is not obvious with empirical genetics work alone (Cowen et al., 2006; Kool et al., 2010).

Dispersal in general is important in selecting habitat, finding unoccupied sites to settle, escaping locally deteriorating environments, founding new populations, and bet hedging on the part of the parental population (Strathmann et al., 2002). However, none of these objectives requires long-distance dispersal, and many actually can be accomplished more successfully by dispersing shorter distances. For instance, long-distance dispersers do not make the best colonizers of new habitat. They may be able to reach new areas more often than shorter distance dispersers, but once they arrive, their highly dispersive larvae will simply be exported from the site (Strathmann et al., 2002). Marine populations therefore achieve closure by developing life histories that retain offspring as members of the reproductive unit (Strathmann et al., 2002). 

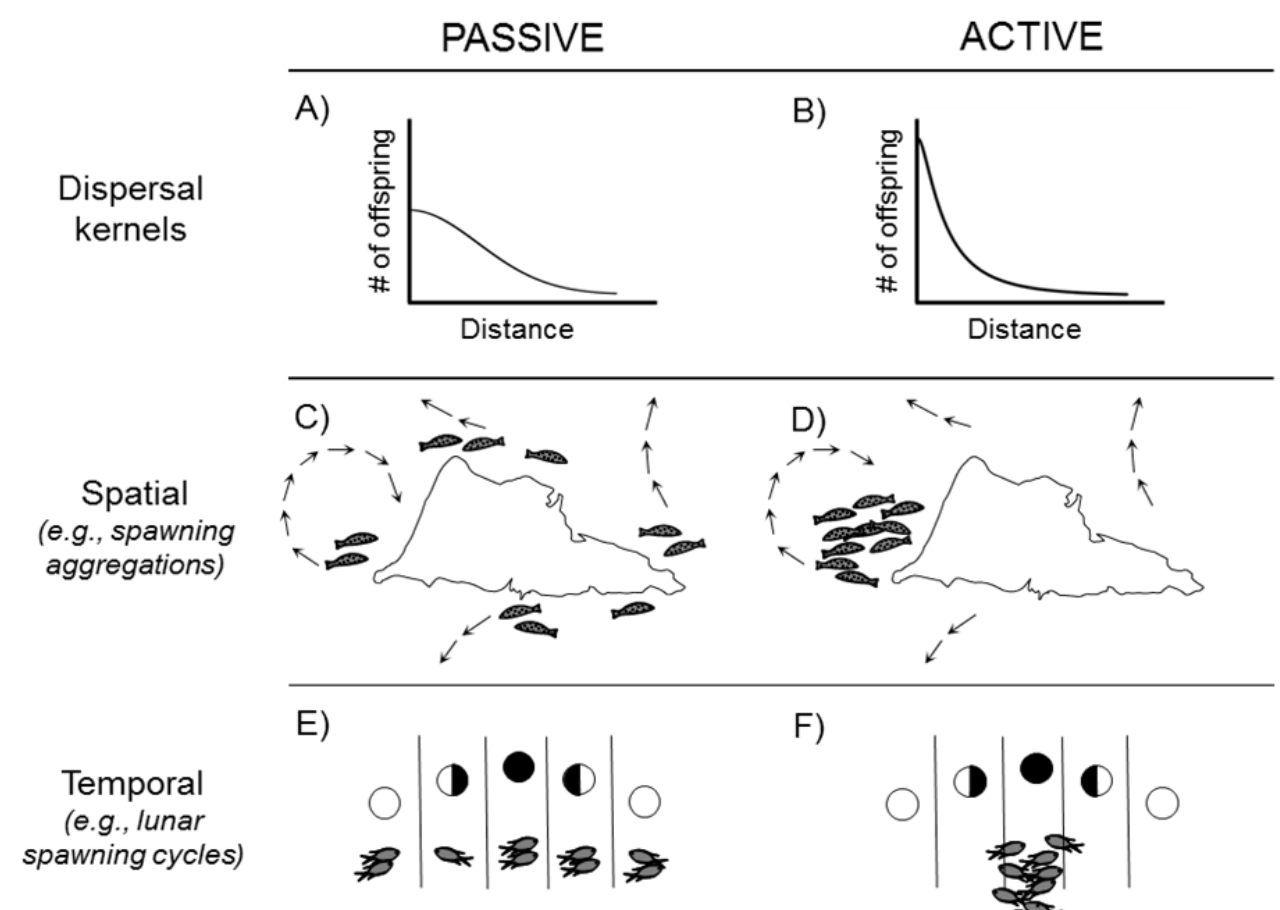

F)

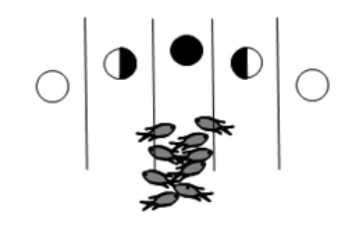

G)

\section{Behavioral \\ (e.g., larval swimming)}

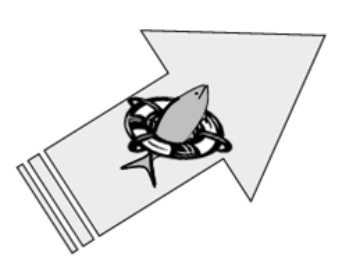

H)

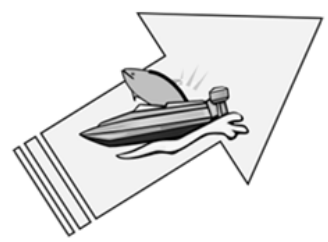

Fig. 2. Passive versus active models of dispersal in coral reef fish. (A \& B) Dispersal kernels describing the density of offspring with increasing distance from a natal reef. Active processes tend to increase the density of offspring near to the source reef (as noted by leptokurtic distribution). A number of species-specific mechanisms can generate limited dispersal. (C \& D) Spawning fish can aggregate in areas near favorable ocean currents, for example retention eddies. (E \& F) Adult fish can time spawning during times of slack tides, reducing advection of larvae from natal reefs. ( $\mathrm{G} \& \mathrm{H}$ ) Larval fish can employ active behaviors (e.g., ballooning across depth strata or swimming) to maintain position near to natal reefs.

If local retention of larvae is so important, why then do about $10 \%$ of reef fish larvae disperse far from home? A traditional explanation of widespread dispersal suggests that it 
could result from the relatively long larval life of many reef fishes, stepping-stone dispersal, travel by larvae in major currents and coastal countercurrents, and/or changes in the direction of major currents over time scales of hundreds to thousands of years (Shulman \& Bermingham, 1995). In contrast, widespread dispersal in reef fishes could also simply be a byproduct of selective pressures that actually favor dispersal over shorter distances, closer to the parental population (Strathmann et al., 2002). For instance, the pelagic phase could have itself developed as an ontogenetic migration into the water column so that larvae can avoid demersal predators, access richer food resources, and/or escape parasites (Johannes, 1978; Swearer et al., 2002). The relatively small percentage of widely dispersing larvae therefore represents "the ones that got away", perhaps carried off by ocean currents. Widely dispersing larvae therefore comprise the tail of a dispersal distribution centered around the parent population. Wide dispersal could also represent an intentional temporary migration away that is followed by a return back to the source area. In other words, larvae that are transported away from their parents will not necessarily settle away from their parents (Strathmann et al., 2002). Even if initially transported several hundred kilometers away, the majority of larvae will recruit close to home (Planes, 2002; Strathmann et al., 2002).

As discussed in earlier sections, genetic similarity between populations can be reinforced by as few as one migrant (or larval propagule) per generation (Planes, 2002). The very existence of long-distance dispersal therefore has genetic consequences, perhaps leading to homogeneity over a large area. However, this model of dispersal posits that demographic (and therefore, ecologically relevant) consequences are driven primarily by patterns of local dispersal and subsequent recruitment (Strathmann et al., 2002).

\subsection{What defines "home"?}

Though the $90 \%$ close to home/10\% far away model of reef fish larval dispersal may be generally true, the geographic distance defining "close to home" depends on the interaction between life history and oceanography, which in turn depends on location and taxa. For instance, even in the absence of any apparent barriers, some Pacific reef fishes with a high dispersal capacity demonstrate high genetic divergence among populations (Fauvelot \& Planes, 2002; Planes et al. 1996; Planes \& Fauvelot, 2002; Riginos and Victor, 2001). This may be related to the degree of isolation of Pacific islands, which makes them good candidates for studies of elevated self-recruitment and other dispersal patterns (Planes et al., 1996; Treml et al., 2008). Because Pacific islands are so far away from each other relative to Caribbean islands, it is logical to expect that local (within-island) retention on ecological scales is more important in the Pacific than in the Caribbean, since longer distance dispersal is unlikely to be sufficiently great to allow larvae to settle at a very distant island. In other words, "close to home" for a reef fish in the Pacific may be at the within-island or withinreef scale, where "close to home" in the Caribbean may be among several relatively closely spaced islands or reef habitats. In addition, the definition of "close to home" is also variable among taxa. Because damselfish and clownfish are brooders, their "close to home" is their coral territory or anemone, respectively. What qualifies as "home" is likely to cover a wider area for species that spawn into the water column. Furthermore, life history traits such as egg size, larvae size, pelagic larval duration, and larval growth rates can vary within reef fish families among different ocean basins (Thresher and Brothers, 1989), supporting the idea that life history traits related to reproduction have evolved to optimize local oceanographic conditions. 


\section{Connectivity is relevant to the management and conservation of coral reef ecosystems}

Coral reefs, which have been called the rainforests of the sea (Connell, 1978), are some of the most biodiverse and productive ecosystems on the planet. They contain an estimated $25 \%$ of all marine species, including thousands of species of fish. Millions of marine species live primarily or exclusively in association with coral reefs. In addition, the economic, social, and cultural importance of coral reefs to humans cannot be overestimated. Over 1 billion people worldwide depend directly on reef resources such as fish, creating an intimate link between reef ecosystem functionality and human wellbeing.

Despite their immense biological and ecological significance, as well as their demonstrated importance to humans, coral reefs are one of the most highly impacted ecosystems on the planet (Halpern et al., 2008). Stressors such as climate change, overfishing, and pollution are causing distributional shifts and biodiversity loss in coral reef ecosystems in many regions of the world (Birkeland, 2004; Graham et al., 2006, 2007; Hughes et al., 2003; Jones et al., 2004; Munday, 2004; Munday et al., 2008; Pandolfi et al., 2003; Wilson et al., 2006, 2008, 2009). In the face of these numerous threats, an improved knowledge of evolutionary and ecological patterns of reef fish connectivity is needed in order to design effective marine protected areas that both conserve biodiversity and enhance fisheries (Almany et al., 2007, 2009; Jones et al., 2009; Palumbi, 2003; Russ, 2002; Sale et al., 2005). In addition, identifying ecological connectivity patterns between fragmented populations can indicate the resilience of species and ecosystems to changing environmental conditions (Jones et al., 2009, 2010; McCook et al., 2009; Planes et al., 1996; Steneck et al., 2009). For instance, because dispersal sustains populations with new recruits (Shanks et al., 2003), high connectivity can both buffer populations from local extirpation and, in the event of a population decline, facilitate post-disturbance recovery.

\section{Conclusions and directions for future research}

Reef fish populations are heterogeneously distributed in space and time, reflecting both the evolutionary origins and ecological maintenance of distribution patterns. Biogeography can be used to inform contemporary patterns of distribution and dispersal. The recognition that reef fish populations could experience high levels of local recruitment and limited larval dispersal was an important paradigmatic shift that refocused studies onto understanding the degree of connectivity among populations, which has important ecological and evolutionary implications. The fact that reef fish dispersal occurs primarily via larval propagules, however, means that connectivity has resisted easy quantification. In order to achieve a more complete picture of population connectivity patterns among coral reef fishes, it must be a research priority to better understand the spatial and temporal variability in larval dispersal and recruitment dynamics across taxa, as well as across ocean basins. This will necessarily involve the development of more sophisticated biophysical models that should be used in conjunction with empirical approaches. Methods that relate genetic structure to estimates of dispersal have been useful, but due to their limitations, they represent only a fraction of the suite of tools that will be necessary for resolving demographically relevant connectivity patterns in reef fishes. A generalized model of dispersal distance based on our current understanding of these patterns proposes that the majority of larvae stay close to home rather than dispersing widely. 
Future research should also bear in mind the influence of anthropogenic factors on connectivity patterns in marine populations. Climate change-related increases in ocean temperatures and changes in weather patterns are projected to alter the speed and direction of major currents, which will affect the physical transport of larvae (Cowen \& Sponaugle, 2009). In addition, increasing habitat fragmentation may play a role in the widely reported local-scale genetic structure in coral reef fishes (Salas et al., 2010), and the benefits of local retention and larval transport are likely to erode in degraded environments (Jones et al., 2009). The disruption of natural patterns of larval retention and connectivity has thus been proposed as a key factor threatening reef fish populations in the coming century (Jones et al., 2009). Given the vulnerability of coral reef ecosystems to global change and other stressors, a more explicit understanding of population connectivity patterns in reef fishes is crucial to their effective management and conservation.

\section{Acknowledgements}

The authors would like to thank Brian Zgliczynski and Ryan Boutin for help with figures, and Currie Saray Dugas for a thoughtful review of this manuscript. R.A. Morrison was supported by a Regents Fellowship from Scripps Institution of Oceanography at the University of California, San Diego.

\section{References}

Almany, G.R., Berumen, M.L., Thorrold, S.R., Planes, S., \& Jones, G.P. (2007). Local replenishment of coral reef fish populations in a marine reserve. Science, Vol. 316, No. 5825, (May 2007), pp. 742-744, 0036-8075

Almany, G.R., Connolly, S.R., Heath, D.D., Hogan, J.D., Jones, G.P., McCook, L.J., Mills, M., Pressey, R.L., \& Williamson, D.H. (2009). Connectivity, biodiversity conservation and the design of marine reserve networks for coral reefs. Coral Reefs, Vol. 28, No. 2, (June 2009), pp. 339-351, 1432-0975

Barber, P.H., Palumbi, S.R., Erdmann, M.V., \& Moosa, M.K. (2000). Biogeography: a marine Wallace's line? Nature, Vol. 406, (August 2000), pp. 692-693, 0028-0836

Barber, P.H., Palumbi, S.R., Erdmann, M.V., \& Moosa, M.K. (2002). Sharp genetic breaks among populations of Haptosquilla pulchella (Stomatopoda) indicate limits to larval transport: patterns, causes, and consequences. Molecular Ecology, Vol. 11, No. 4, (April 2002), pp. 659-674, 1365-294X

Baums, I.B., Paris, C.B., \& Chérubin, L.M. (2006). A bio-oceanographic filter to larval dispersal in a reef-building coral. Limnology and Oceanography, Vol. 51, No. 5 (September 2006), pp. 1969-1981, 0024-3590

Bay, L.K., Choat, J.H., van Herwerden, L., \& Robertson, D.R. (2003). High genetic diversities and complex genetic structure in an Indo- Pacific tropical reef fish (Chlorurus sordidus): evidence of an unstable evolutionary past? Marine Biology, Vol. 144, No. 4, (April 2004), pp. 757-767, 1687-9481

Bellwood, D.R. (1996). The Eocene fishes of Monte Bolca: the earliest coral reef fish assemblage. Coral Reefs, Vol. 15, No. 1, (March 1996), pp. 11-19, 1432-0975

Bellwood, D.R. \& Wainwright, P.C. (2002). The history and biogeography of fishes on coral reefs, In: Coral Reef Fishes: Dynamics and Diversity in a Complex Ecosystem, P.F. Sale, pp. 5-32, Academic Press, 978-0126151855, Boston, MA, USA 
Bentzen, P., Taggart, C.T., Ruzzante, D.E., \& Cook, D. (1996). Microsatellite polymorphism and the population structure of Atlantic cod (Gadus morhua) in the northwest Atlantic. Canadian Journal of Fisheries and Aquatic Sciences, Vol. 53, No. 12, (December 1996), pp. 2706-2721, 1205-7533

Birkeland, C. (2004). Ratcheting down the coral reefs. BioScience, Vol. 54, No. 11, (November 2004), pp. 1021-1027, 0006-3568

Block, B.A., Teo, S.L.H., Walli, A., Boustany, A., Stokesbury, M.J.W., Farwell, C.J., Weng, K.C., Dewar, H., \& Williams, T.D. (2005). Electronic tagging and population structure of Atlantic bluefin tuna. Nature, Vol. 434, (April 2005), pp. 1121-1127, 0028-0836

Bohonak, A.J. (1999). Dispersal, gene flow, and population structure. The Quarterly Review of Biology, Vol. 74, No. 1, (March 199), pp. 21-45, 0033-5770

Botsford, L.W., White, J.W., Coffroth, M.-A., Paris, C.B., Planes, S., Shearer, T.L., Thorrold, S.R. \& Jones, G.P. (2009). Connectivity and resilience of coral reef metapopulations in marine protected areas: matching empirical efforts to predictive needs. Coral Reefs, Vol. 28, No. 2, (June 2009), pp. 327-337, 1432-0975

Bowen, B.W., Bass, A.L., Muss, A., Carlin, J.L., \& Robertson, D.R. (2006). Phylogeography of two Atlantic squirrelfishes (Family Holocentridae): exploring links between pelagic larval duration and population connectivity. Marine Biology, Vol. 149, No. 4, (July 2006), pp. 899-913, 1687-9481

Briggs, J.C. (1974). Marine Zoogeography. McGraw-Hill, 978-0070078000, New York, NY, USA

Briggs, J.C. (2007). Marine longitudinal biodiversity: causes and conservation. Diversity and Distributions, Vol. 13, No. 5, (September 2007), pp. 544-555, 1472-4642

Burton, R.S. (1996). Molecular tools in marine ecology. Journal of Experimental Marine Biology and Ecology, Vol. 200, No. 1-2, (November 1996), pp. 85-101, 0022-0981

Burton, R.S. (2009). Molecular markers, natural history, and conservation of marine animals. BioScience, Vol. 59, No. 10, (November 2009) pp. 831-840, 0006-3568

Carlsson, J., McDowell, J.R., Díaz-James, P., Carlsson, J.E.L., Boles, S.B., Gold, J.R., \& Graves, J.E. (2004). Microsatellite and mitochondrial DNA analyses of Atlantic bluefin tuna (Thunnus thynnus thynnus) population structure in the Mediterranean Sea. Molecular Ecology, Vol. 13, No. 11, (November 2004), pp. 3345-3356, 1365-294X

Christie, M.R., Johnson, D.W., Stallings, C.D., \& Hixon, M.A. (2010). Self-recruitment and sweepstakes reproduction amid extensive gene flow in a coral-reef fish. Molecular Ecology, Vol. 19, No. 5, (March 2010), pp. 1042-1057, 1365-294X

Craig, M.T., Eble, J.A., Bowen, B.W., \& Robertson, D.R. (2007). High genetic connectivity across the Indian and Pacific Oceans in the reef fish Myripristis berndti (Holocentridae). Marine Ecology Progress Series, Vol. 334, (March 2007), pp. 245-254, 1616-1599

Connell, J.H. (1978). Diversity in tropical rain forests and tropical reefs. Science, Vol. 199, No. 4335, (March 1978), pp. 1302-1310, 0036-8075

Cowen, R.K. (2002). Larval dispersal and retention and consequences for marine population connectivity, In: Coral Reef Fishes: Dynamics and Diversity in a Complex Ecosystem, P.F. Sale, pp. 149-170, Academic Press, Boston, MA, USA

Cowen, R.K., Paris, C.B., \& Srinivasan, A. (2006). Scaling of connectivity in marine populations. Science, Vol. 311, No. 5760, (January 2006), pp. 522-527, 0036-8075 
Cowen, R.K. \& Sponaugle, S. (2009). Larval dispersal and marine population connectivity. Annual Review of Marine Science, Vol. 1, (January 2009), pp. 443-466, 1941-0611

DiBattista, J.D., Wilcox, C., Craig, M.T., Rocha, L.A., \& Bowen, B.W. (2011). Phylogeography of the Pacific blueline surgeonfish, Acanthurus nigroris, reveals high genetic connectivity and a cryptic endemic species in the Hawaiian archipelago. Journal of Marine Biology, Vol. 2011, (October 2010), pp. 1-17, 1687-9481

Drew, J.A., Allen, G.R., Kaufman, L., \& Barber, P.H. (2008). Endemism and regional color and genetic differences in five putatively cosmopolitan reef fishes. Conservation Biology, Vol. 22, No. 4, (August 2008), pp. 965-975, 0888-8892

Eble, J.A., Rocha, L.A., Craig, M.T., \& Bowen, B.W. (2011). Not all larvae stay close to home: insights into marine population connectivity with a focus on the brown surgeonfish (Acanthurus nigrofuscus). Journal of Marine Biology, Vol. 2011, (September 2010), pp. 1-12, 1687-9481

Ehrlich, P.R. (1975). The population biology of coral reef fishes. Annual Review of Ecology, Evolution, and Systematics, Vol. 6 (December 1975), pp. 211-247, 00664162

Evans, R.D., van Herwerden, L., Russ, G.R., \& Frisch, A.J. (2010). Strong genetic but not spatial subdivision of two reef fish species targeted by fishers on the Great Barrier Reef. Fisheries Research, Vol. 102, No. 1-2, (February 2010), pp. 16-25, 1872-6763

Fauvelot, C., Lemaire, C., Planes, S., \& Bonhomme, F. (2007). Inferring gene flow in coral reef fishes from different molecular markers: which loci to trust? Heredity, Vol. 99, (May 2009), pp. 331-339, 0018-067X

Fauvelot, C. \& Planes, S. (2002). Understanding origins of present-day genetic structure in marine fish: biologically or historically driven patterns? Marine Biology, Vol. 141, No. 4, (October 2002), pp. 773-788, 1687-9481

Fink, B.D. \& Bayliff, W.H. (1970). Migrations of yellowfin and skipjack tuna in the Eastern Pacific Ocean as determined by tagging experiments, 1952-1964. Inter-American Tropical Tuna Commission Bulletin, Vol. 15, No. 1., (1970), pp. 1-227, 0074-0993

Floeter, S.R., Rocha, L.A., Robertson, D.R., Joyeux, J.C., Smith-Vaniz, W.F., Edwards, A.J., Barreiros, J.P., Ferreira, C.E.L., Gasparini, J.L., Brito, A., Falcón, J.M., Bowen, B.W., \& Bernardi, G. (2008). Atlantic reef fish biogeography and evolution. Journal of Biogeography, Vol. 35, No. 1, (January 2008), pp. 22-47, 1365-2699

Galarza, J.A., Carreras-Carbonell, J., Macpherson, E., Pascual, M., Roques, S., Turner, G.F., \& Rico, C. (2009). The influence of oceanographic fronts and early-life-history traits on connectivity among littoral fish species. Proceedings of the National Academy of Sciences of the United States of America, Vol. 106, No. 5, (February 2009), pp. 1473$1478,0027-8424$

Galindo, H.M., Olson, D.B., \& Palumbi, S.R. (2006). Seascape genetics: a coupled oceanographic-genetic model predicts population structure of Caribbean corals. Current Biology, Vol. 16, No. 16, (August 2006), pp. 1622-1626, 0960-9822

Gaylord, B. \& Gaines, S.D. (2000). Temperature or transport? Range limits in marine species mediated solely by flow. American Naturalist, Vol. 155, No. 6, (June 2000), pp. 769789, 0003-0147

Geertjes, G.J., Postema, J., Kamping, A., van Delden, W., Videler, J.J., \& van de Zande, L. (2004). Allozymes and RAPDs detect little population substructuring in the Caribbean stoplight parrotfish Sparisoma viride. Marine Ecology Progress Series, Vol. 279, (September 2004), pp. 225-235, 1616-1599 
Gerlach, G., Atema, J., Kingsford, M.J., Black, K.P., \& Miller-Sims, V. (2007). Smelling home can prevent dispersal of reef fish larvae. Proceedings of the National Academy of Sciences of the United States of America, Vol. 104, No. 3, (January 2007), pp. 858-863, 0027-8424

Graham, N.A.J., McClanahan, T.R., Letourneur, Y., \& Galzin, R. (2007). Anthropogenic stressors, inter-specific competition and ENSO effects on a Mauritian coral reef. Environmental Biology of Fishes, Vol. 78, No. 1, (January 2007), pp. 57-69, 0378-1909

Graham, N.A.J., Wilson, S.K., Jennings, S., Polunin, N.V.C., Bijoux, J.P., \& Robinson, J. (2006). Dynamic fragility of oceanic coral reef ecosystems. Proceedings of the National Academy of Sciences of the United States of America, Vol. 103, No. 22, (May 2006), pp. 8425-8429

Grosberg, R. \& Cunningham, C.W. (2001). Genetic structure in the sea: from populations to communities, In: Marine Community Ecology, M.D. Bertness, S. Gaines, \& M.E. Hay, pp. 61-84, Sinauer Associates, 978-0878930579, Sunderland, MA, USA

Halpern, B.S., Walbridge, S., Selkoe, K.A., Kappel, C.V., Micheli, F., D'Agrosa, C., Bruno, J.F., Casey, K.S., Ebert, C., Fox, H.E., Fujita, R., Heinemann, D., Lenihan, H.S., Madin, E.M.P., Perry, M.T., Selig, E.R., Spalding, M., Steneck, R., \& Watson, R. (2008). A global map of human impact on marine ecosystems. Science, Vol. 319, No. 5865, (February 2008), pp. 948-952, 0036-8075

Hartwell, L., Hood, L., Goldberg, M., Reynolds, A., Silver, L., \& Veres, R.C. (2008). Genetics: From Genes to Genomes, McGraw-Hill, 978-0073227382, New York, NY, USA

Hebert, P.D.N., Cywinska, A., Ball, S.L., \& deWaard, J.R. (2003). Biological identifications through DNA barcodes. Proceedings of the Royal Society of London, Series B, Vol. 270, No. 1512, (February 2003), pp. 313-321, 1471-2954

Hedgecock, D., Barber, P.H., \& Edmands, S. (2007). Genetic approaches to measuring connectivity. Oceanography, Vol. 20, No. 3, (September 2007), pp. 70-79, 1042-8275

Hellberg, M.E. (2007). Footprints on water: the genetic wake of dispersal among reefs. Coral Reefs, Vol. 26, No. 3, (September 2007), pp 463-473, 1432-0975

Hellberg, M.E. (2009). Gene flow and isolation among populations of marine animals. Annual Review of Ecology, Evolution, and Systematics, Vol. 40, (December 2009), pp. 291-310, 1543-592X

Hellberg, M.E., Burton, R.S., Neigel, J.E., \& Palumbi, S.R. (2002). Genetic assessment of connectivity among marine populations. Bulletin of Marine Science, Vol. 70, No. 1, (January 2002), pp. 273-290, 1553-6955

Hepburn, R.I., Sale, P.F., Dixon, B., \& Heath, D.D. (2009). Genetic structure of juvenile cohorts of bicolor damselfish (Stegastes partitus) along the Mesoamerican barrier reef: chaos through time. Coral Reefs, Vol. 28, No. 1, (March 2009), pp. 277-288, 14320975

Hixon, M.A., Pacala, S.W., \& Sandin, S.A. (2002). Population regulation: historical context and contemporary challenges of open vs. closed systems. Ecology, Vol. 83, No. 6, (June 2002), pp. 1490-1508, 0012-9658

Hogan, J.D., Thiessen, R.J., \& Heath, D.D. (2010). Variability in connectivity indicated by chaotic genetic patchiness within and among populations of a marine fish. Marine Ecology Progress Series, Vol. 417, (November 2010), pp. 263-275, 1616-1599

Horne, J.B., van Herwerden, L., Choat, J.H., \& Robertson, D.R. (2008). High population connectivity across the Indo-Pacific: congruent lack of phylogeographic structure in 
three reef fish congeners. Molecular Phylogenetics and Evolution, Vol. 49, No. 2, (November 2008), pp. 629-638, 1055-7903

Hughes, T.P., Baird, A.H., Bellwood, D.R., Card, M., Connolly, S.R., Folke, C., Grosberg, R., Hoegh-Guldberg, O., Jackson, J.B.C., Kleypas, J., Lough, J.M., Marshall, P., Nyström, M., Palumbi, S.R., Pandolfi, J.M., Rosen, B., \& Roughgarden, J. (2003). Climate change, human impacts, and the resilience of coral reefs. Science, Vol. 301, No. 5635, (August 2003), pp. 929-933, 0036-8075

James, M.K., Armsworth, P.R., Mason, L.B., \& Bode, L. (2002). The structure of reef fish metapopulations: modelling larval dispersal and retention patterns. Proceedings of the Royal Society of London, Series B, Vol. 269, No. 1505, (October 2002), pp. 20792086, 1471-2954

Johannes, R.E. (1978). Reproductive strategies of coastal marine fishes in the tropics. Environmental Biology of Fishes, Vol. 3, No. 1, (March 1978), pp. 65-84, 1573-5133

Johnson, M.S. \& Black, R. (1982). Chaotic genetic patchiness in an intertidal limpet, Siphonaria spp. Marine Biology, Vol. 70, No. 2, (September 1982), pp. 157-164, 16879481

Jones, G.P., Almany, G.R., Russ, G.R., Sale, P.F., Steneck, R.S., van Oppen, M.J.H., \& Will, B.L. (2009). Larval retention and connectivity among populations of corals and reef fishes: history, advances, and challenges. Coral Reefs, Vol. 28, No. 2, (June 2009), pp. 307-325, 1432-0975

Jones, G.P., Jerry, D.R., McCormick, M.I., \& Bay, L.K. (2010). The population genetic structure of a common tropical damselfish on the Great Barrier Reef and eastern Papua New Guinea. Coral Reefs, Vol. 29, No. 2, (June 2010), pp. 455-467, 1432-0975

Jones, G.P., McCormick, M.I., Srinivasan, M., \& Eagle, J.V. (2004). Coral decline threatens fish biodiversity in marine reserves. Proceedings of the National Academy of Sciences of the United States of America, Vol. 101, No. 21, (May 2004), pp. 8251-8253

Jones, G.P., Milicich, M.J., Emslie, M.J., \& Lunow, C. (1999). Self-recruitment in a coral reef fish population. Nature, Vol. 402, (December 1999), pp. 802-804, 0028-0836

Jones, G.P., Planes, S., \& Thorrold, S.R. (2005). Coral reef fish larvae settle close to home, Vol. 15, No. 14, (July 2005), pp. 1314-1318, 0960-9822

Kimura, M. \& Weiss, G.H. (1964). The stepping stone model of population structure and the decrease of genetic correlation with distance. Genetics, Vol. 49, No. 4, (April 1964), pp. 561-576, 0975-2862

Kingsford, M.J., Leis, J.M., Shanks, A., Lindeman, K.C., Morgan, S.G., \& Pineda, J. (2002). Sensory environments, larval abilities, and local self-recruitment. Bulletin of Marine Science, Vol. 70, No. 1, (January 2002), pp. 309-340, 1553-6955

Klanten, O.S., Choat, J.H., \& van Herwerden, L. (2007). Extreme genetic diversity and temporal rather than spatial partitioning in a widely distributed coral reef fish. Marine Biology, Vol. 150, No. 4, (January 2007), pp. 659-670, 1687-9481

Knowlton, N. (1993). Sibling species in the sea. Annual Review of Ecology, Evolution, and Systematics, Vol. 24, (December 1993), pp. 189-216, 1545-2069

Kool, J.T., Paris, C.B., Andréfouët, S., \& Cowen, R.K. (2010). Complex migration and the development of genetic structure in subdivided populations: an example from Caribbean coral reef ecosystems. Ecography, Vol. 33, No. 3, (June 2010), pp. 597-606, 0906-7590 
Lacson, J.M. (1992). Minimal genetic variation among samples of six species of coral reef fishes collected at La Parguera, Puerto Rico, and Discovery Bay, Jamaica. Marine Biology, Vol. 112, No. 2, (June 1992), pp. 327-331, 1687-9481

Largier, J. (2003). Considerations in estimating larval dispersal distances from oceanographic data. Ecological Applications, Vol. 13, No. 1, (February 2003), pp. S71S89, 1051-0761

Largier, J. (2004). The importance of retention zones in the dispersal of larvae. American Fisheries Society Symposium, Vol. 42, pp. 105-122, 0892-2284

Leis, J.M. (2002). Pacific coral-reef fishes: the implications of behavior and ecology of larvae for biodiversity and conservation, and a reassessment of the open population paradigm. Environmental Biology of Fishes, Vol. 65, No. 2, (October 2002), pp. 199208, 1573-5133

Leis, J.M. \& McCormick, M.I. (2002) The biology, behavior, and ecology of the pelagic, larval stage of coral reef fishes, In: Coral Reef Fishes: Dynamics and Diversity in a Complex Ecosystem, P.F. Sale, pp. 171-200, Academic Press, 978-0126151855, Boston, MA, USA

Lessios, H.A. \& Robertson, D.R. (2006). Crossing the impassable: genetic connections in 20 reef fishes across the eastern Pacific barrier. Proceedings of the Royal Society of London, Series B, Vol. 273, No. 1598, (September 2006), pp. 2201-2208, 1471-2954

Lester, S.E. \& Ruttenberg, B.I. (2005). The relationship between pelagic larval duration and range size in tropical reef fishes: a synthetic analysis. Proceedings of the Royal Society of London, Series B, Vol. 272, No. 1563, (March 2005), pp. 585-591, 1471-2954

Lester, S.E., Ruttenberg, B.I., Gaines, S.D., \& Kinlan, B.P. (2007). The relationship between dispersal ability and geographic range size. Ecology Letters, Vol. 10, No. 8, (August 2007), pp. 745-758, 1461-0248

Lobel, P.S. (1989). Ocean current variability and the spawning season of Hawaiian reef fishes. Environmental Biology of Fishes, Vol. 24, No. 3, (March 1989), pp. 161-171, 1573-5133

Lobel, P.S. (1997). Comparative settlement age of damselfish larvae (Plectroglyphidodon imparipennis, Pomacentridae) from Hawaii and Johnston Atoll. The Biological Bulletin, Vol. 193, (October 1997), pp. 281-283, 1939-8697

MacArthur, R.H. \& Wilson, E.O. (1967). The Theory of Island Biogeography, Princeton University Press, 978-0691088365, Princeton, NJ, USA

McCook, L.J., Almany, G.R., Berumen, M.L., Day, J.C., Green, A.L., Jones, G.P., Leis, J.M., Planes, S., Russ, G.R., Sale, P.F., \& Thorrold, S.R. (2009). Management under uncertainty: guide-lines for incorporating connectivity into the protection of coral reefs. Coral Reefs, Vol. 28, No. 2, (June 2002), pp. 353-366, 1432-0975

Mora, C., Chittaro, P.M., Sale, P.F., Kritzer, J.P., \& Ludsin, S.A. (2003). Patterns and processes in reef fish diversity. Nature, Vol. 421, (February 2003), pp. 933-936, 00280836

Mora, C. \& Sale, P.F. (2002). Are populations of coral reef fish open or closed? Trends in Ecology and Evolution, Vol. 17, No. 9, (September 2002), pp. 422-428, 0169-5347

Munday, P.L. (2004). Habitat loss, resource specialization, and extinction on coral reefs. Global Change Biology, Vol. 10, No. 10, (October 2004), pp. 1642-1647, 1365-2486 
Munday, P.L., Jones, G.P., Pratchett, M.S., \& Williams, A.J. (2008). Climate change and the future for coral reef fishes. Fish and Fisheries, Vol. 9, No. 3, (September 2008), pp. 261-285, 1467-2979

Muss, A., Robertson, D.R., Stepien, C.A., Wirtz, P., \& Bowen, B.W. (2001). Phylogeography of Ophioblennius: the role of ocean currents and geography in reef fish evolution. Evolution, Vol. 5, No. 3 (March 2001), pp. 561-572, 0066-4162

Palumbi, S.R. (1994). Genetic divergence, reproductive isolation, and marine speciation. Annual Review of Ecology, Evolution, and Systematics, Vol. 25, (December 1995), pp. 547-572, 1543-592X

Palumbi, S.R. (2003). Population genetics, demographic connectivity, and the design of marine reserves. Ecological Applications, Vol. 13, No. 1, (February 2003), S146-S158, 1051-0761

Pandolfi, J.M., Bradbury, R.H., Sala, E., Hughes, T.P., Bjorndal, K.A., Cooke, R.G., McArdle, D., McClenachan, L., Newman, M.J.H., Paredes, G., Warner, R.R., \& Jackson, J.B.C. (2003). Global trajectories of the long-term decline of coral reef ecosystems. Science, Vol. 301, No. 5635, (August 2003), pp. 955-958, 0036-8075

Pelc, R.A., Warner, R.R., \& Gaines, S.D. (2009). Geographical patterns of genetic structure in marine species with contrasting life histories. Journal of Biogeography, Vol. 36, No. 10, (June 2009), pp. 1881-1890, 1365-2699

Planes, S. (2002). Biogeography and larval dispersal inferred from population genetic analysis, In: Coral Reef Fishes: Dynamics and Diversity in a Complex Ecosystem, P.F. Sale, pp. 201-220, Academic Press, 978-0126151855, Boston, MA, USA

Planes, S., Doherty, P.J., \& Bernardi, G. (2001). Strong genetic divergence among populations of a marine fish with limited dispersal, Acanthochromis polyacanthus, within the Great Barrier Reef and the Coral Sea. Evolution, Vol. 55, No. 11, (November 2001), pp. 2263-2273, 0014-3820

Planes, S. \& Fauvelot, C. (2002). Isolation by distance and vicariance drive genetic structure of a coral reef fish in the Pacific Ocean. Evolution, Vol. 56, No. 2, (May 2001), pp. 378-399, 0014-3820

Planes, S., Galzin, R., \& Bonhomme, F. (1996). A genetic metapopulation model for reef fishes in oceanic islands: the case of the surgeonfish, Acanthuras triostegus. Journal of Evolutionary Biology, Vol. 9, No. 1, (January 1996), pp. 103-117, 1010-061X

Planes, S., Roman, P., \& Lecomte-Finiger, R. (1998). Genetic evidence of closed life-cycles for some coral reef fishes within Taiaro Lagoon (Tuamotu Archipelago, French Polynesia). Coral Reefs, Vol. 17, (August 1997), pp. 9-14, 0722-4028

Planes, S., Jones, G.P., \& Thorrold, S.R. (2009). Larval dispersal connects fish populations in a network of marine protected areas. Proceedings of the National Academy of Sciences, Vol. 106, No. 14, (April 2009), pp. 5693-5697, 0027-8424

Purcell, J.F.H., Cowen, R.K., Hughes, C.R., \& Williams, D.A. (2006). Weak genetic structure indicates strong dispersal limits: a tale of two coral reef fish. Proceedings of the Royal Society of London, Series B, Vol. 273, No. 1593, (June 2006), pp. 1483-1490, 1471-2954

Ray, G.C., Mitchell, E.D., Wartzok, D., Kozicki, V.M., \& Maiefski, R. (1978). Radio tracking of a fin whale (Balaenoptera physalus). Science, Vol. 202, No. 4367, (November 1978), pp. 521-524, 0036-8075 
Richards, S.R., Possingham, H.P., \& Noye, B. (1995). Larval dispersion along a straight coast with tidal currents: complex distribution patterns from a simple model. Marine Ecology Progress Series, Vol. 122, (June 1995), pp. 59-71, 0171-8630

Riginos, C., \& Victor, B.C. (2001). Larval spatial distributions and other early life-history characteristics predict genetic differentiation in eastern Pacific blennioid fishes. Proceedings of the Royal Society of London, Series B, Vol. 268, No. 1479, (September 2001), pp. 1931-1936, 1471-2954

Rivera, M.A.J., Andrews, K.R., Kobayashi, D.R., Wren, J.L.K., Kelley, C., Roderick, G.K., \& Toonen, R.J. (2006). Genetic analyses and simulations of larval dispersal reveal distinct populations and directional connectivity across the range of the Hawaiian grouper (Epinephelus quernus). Journal of Marine Biology, Vol. 2011, (September 2010), pp. 1-11, 1687-9481

Roberts, C.M. (1997). Connectivity and management of Caribbean coral reefs. Science, Vol. 278, No. 5342, (November 1997), pp. 1454-1457, 0036-8075

Rocha, L.A. (2003). Patterns of distribution and processes of speciation in Brazilian reef fishes. Journal of Biogeography, Vol. 30, No. 8, (August 2003), pp. 1161-1171, 13652699

Rocha L.A., Craig M.T., \& Bowen B.W. (2007). Phylogeography and the conservation of coral reef fishes. Coral Reefs, Vol. 26 No. 3, (November 2006), pp. 501-512, 1432-0975

Roughgarden, J., Pennington, J.T., Stoner, D., Alexander, S., \& Miller, K. (1991). Collisions of upwelling fronts with the intertidal zone: The cause of recruitment pulses in barnacle populations of central California. Acta Oecologica, Vol. 12, No. 1, (JanuaryFebruary 1991), pp. 35-51, 1146-609X

Russ, G.R. (2002). Yet another review of marine reserves as reef fishery management tools, In: Coral Reef Fishes: Dynamics and Diversity in a Complex Ecosystem, P.F. Sale, pp. 421-443, Academic Press, 978-0126151855, Boston, MA, USA

Ruzzante, D.E., Wroblewski, J.S., Taggart, C.T., Smedbol, R.K., Cook, D., \& Goddard, S.V. (2000). Bay-scale population structure in coastal Atlantic cod in Labrador and Newfoundland, Canada. Journal of Fish Biology, Vol. 56, No. 2, (February 2000), pp. 431-447, 1095-8649

Saenz-Agudelo, P., Jones, G.P., Thorrold, S.R., \& Planes, S. (2009). Estimating connectivity in marine populations: an empirical evaluation of assignment tests and parentage analysis under different gene flow scenarios. Molecular Ecology, Vol. 18, No. 8, (December 2008), pp. 1765-1776, 1365-294X

Salas, E., Molina-Ureña, U. Walter, R.P., \& Heath, D.D. (2009). Local and regional genetic connectivity in a Caribbean coral reef fish. Marine Biology, Vol. 157, No. 2, (October 2009), pp. 437-445, 0025-3162

Sale, P.F., Cowen, R.K., Danilowicz, B.S., Jones, G.P., Kritzer, J.P., Lindeman, K.C., Planes, S., Polunin, N.V.C., Russ, G.R., Sadovy, Y.J., \& Steneck, R.S. (2005). Critical science gaps impede use of no-take fishery reserves. Trends in Ecology and Evolution, Vol. 20, No. 2, (February 2005), pp. 74-80, 0169-5347

Sandin, S.A., Vermeij, M.J.A., Hurlbert, A.H. (2008). Island biogeography of Caribbean coral reef fish. Global Ecology and Biogeography, Vol. 17, No. 6, (November 2008), pp. 770$777,1466-8238$ 
Selkoe, K.A., Henzler, C.M., \& Gaines, S.D. (2008). Seascape genetics and the spatial ecology of marine populations. Fish and Fisheries, Vol. 9, No. 4, (December 2008), pp. 363$377,1467-2979$

Selkoe, K.A., Watson, J.R., White, C., Ben Horin, T., Iachhei, M., Mitarai, S., Siegel, D.A., Gaines, S.D., \& Toonen, R.J. (2010). Taking the chaos out of genetic patchiness: seascape genetics reveals ecological and oceanographic drivers of genetic patterns in three temperate reef species. Molecular Ecology, Vol. 19, No. 17, (September 2010), pp. 3708-3726, 1365-294X

Shanks, A.L., Grantham, B.A., \& Carr, M.H. (2003). Propagule dispersal distance and the size and spacing of marine reserves. Ecological Applications, Vol. 13, No. 1, (February 2003), pp. S159-S169, 1051-0761

Shulman, M.J. (1998). What can population genetics tell us about dispersal and biogeographic history of coral-reef fishes? Australian Journal of Ecology, Vol. 23, No. 3, (June 1998), pp. 216-225, 0307-692X

Shulman, M.J. \& Bermingham, E. (1995). Early life histories, ocean currents, and the population genetics of Caribbean reef fishes. Evolution, Vol. 49, No. 5, (October 1995), pp. 897-910, 0066-4162

Schultz, J.K., Pyle, R.L., DeMartini, E., \& Bowen, B.W. (2007). Genetic connectivity among color morphs and Pacific archipelagos for the flame angelfish, Centropyge loriculus. Marine Biology, Vol. 151, No. 1, (January 2006), pp. 167-175, 1687-9481

Slatkin, M. (1987). Gene flow and the geographic structure of natural populations. Science, Vol. 236, No. 4803, (May 1987), pp. 787-792, 0036-8075

Slatkin, M. (1993). Isolation by distance in equilibrium and non-equilibrium populations. Evolution, Vol. 47, No. 1, (February 1993), pp. 264-279, 0066-4162

Sponaugle, S., Cowen, R.K., Shanks, A., Morgan, S.G., Leis, J.M., Pineda, J., Boehlert, G.W., Kingsford, M.J., Lindeman, K.C., Grimes, C., \& Munro, J.L. (2002). Predicting selfrecruitment in marine populations: biophysical correlates and mechanisms. Bulletin of Marine Science, Vol. 70, No. 1, (January 2002), pp. 341-375, 1553-6955

Springer, V.G. (1982). Pacific plate biogrography, with special reference to shorefishes. Smithsonian Contributions to Zoology, Vol. 69, No. 2. (January 2007), pp. 289-290, 0081-0282

Steneck, R.S., Paris, C.B., Arnold, S.N., Ablan-Lagman, M.C., Alcala, A.C., Butler, M.J., McCook, L.J., Russ, G.R., \& Sale, P.F. (2009). Thinking and managing outside the box: coalescing connectivity networks to build region-wide resilience in coral reef ecosystems. Coral Reefs, Vol. 28, No. 2, (June 2009), pp. 367-378, 1432-0975

Strathmann, R.R., Hughes, T.P., Kuris, A.M., Lindeman, K.C., Morgan, S.G., Pandolfi, J.M., \& Warner, R.R. (2002). Evolution of local recruitment and its consequences for marine populations. Bulletin of Marine Science, Vol. 70, No. 1, (January 2002), pp. 377-396, 1553-6955

Swearer, S.E., Caselle, J.E., Lea, D.W., \& Warner, R.R. (1999). Larval retention and recruitment in an island population of a coral reef fish. Nature, Vol. 402, (December 1999), pp. 799-802, 0028-0836

Swearer, S.E., Shima, J.S., Hellberg, M.E., Thorrold, S.R., Jones, G.P., Robertson, D.R., Morgan, S.G., Selkoe, K.A., Ruiz, G.M., \& Warner, R.R. (2002). Evidence of selfrecruitment in demersal marine populations. Bulletin of Marine Science, Vol. 70, No. 1, (January 2002), pp. 251-271, 1553-6955 
Taylor, M.S. \& Hellberg, M.E. (2003). Genetic evidence for local retention of pelagic larvae in a Caribbean reef fish. Science, Vol. 299, No. 5603, (January 2003), pp. 107-109, 00368075

Thorrold, S.R., Jones, G.P., Hellberg, M.E., Burton, R.S., Swearer, S.E., Neigel, J.E., Morgan, S.G., \& Warner, R.R. (2002). Quantifying larval retention and connectivity in marine populations with artificial and natural markers. Bulletin of Marine Science, Vol. 70, No. 1, (January 2002), pp. 291-308, 1553-6955

Thresher, R.E. \& Brothers, E.B. (1989). Evidence of intra-and inter-oceanic regional differences in the early life history of reef-associated fishes. Marine Ecology Progress Series, Vol. 57, No. 2, (October 1989), pp. 187-205, 1616-1599

Toonen, R.J., Andrews, K.R., Baums, I.B., Bird, C.E., Concepcion, G.T., Daly-Engel, T.S., Eble, J.A., Faucci, A., Gaither, M.R., Iacchei, M., Puritz, J.B., Schultz, J.K., Skillings, D.J., Timmers, M.A., \& Bowen, B.W. (2011). Defining boundaries for ecosystem-based management: a multispecies case study of marine connectivity across the Hawaiian archipelago. Journal of Marine Biology, Vol. 2011, (November 2010), pp. 1-13, 16879481

Treml, E.A., Halpin, P.N., Urban, D.L., \& Pratson, L.F. (2008). Modeling population connectivity by ocean currents, a graph-theoretic approach for marine conservation. Landscape Ecology, Vol. 23, No. S1, (July 2007), pp. 19-36, 1921-2373

Victor, B.C. \& Wellington, G.M. (2000). Endemism and the pelagic larval duration of reef fishes in the eastern Pacific Ocean. Marine Ecology Progress Series, Vol. 205, (October 2000), pp. 241-248, 1616-1599

Visram, S., Yang, M-C., Pillay, R.M., Said, S., Henriksson, O., Grahn, M., \& Chen, C.A. (2010). Genetic connectivity and historical demography of the blue barred parrotfish (Scarus ghobban) in the western Indian Ocean. Marine Biology, Vol. 157, No. 7, (July 2010), pp. 1475-1487, 1432-1793

Weersing, K. \& Toonen, R.J. (2009). Population genetics, larval dispersal, and connectivity in marine systems. Marine Ecology Progress Series, Vol. 393, (October 2009), pp. 1-12, 1616-1599

Wilson, S.K., Graham, N.A.J., Pratchett, M.S., Jones, G.P., \& Polunin, N.V.C. (2006). Multiple disturbances and the global degradation of coral reefs: are reef fishes at risk or resilient? Global Change Biology, Vol. 12, No. 11, (November 2006), pp. 2220-2234, 1365-2486

Wilson, S.K., Fisher, R., Pratchett, M.S., Graham, N.A.J., Dulvy, N.K., Turner, R.A., Cakacaka, A., Polunin, N.V.C., \& Rushton, S.P. (2008). Exploitation and habitat degradation as agents of change within coral reef fish communities. Global Change Biology, Vol. 14, No. 12, (December 2008), pp. 2796-2809, 1365-2486

Wilson, S.K., Dolman, A.M., Cheal, A.J., Emslie, M.J., Pratchett, M.S., \& Sweatman, H.P.A. (2009). Maintenance of fish diversity on disturbed coral reefs. Coral Reefs, Vol. 28, No. 1, (October 2008), pp. 3-14, 1432-0975

Wood, R.A. (1999). Reef Evolution. Oxford University Press, 0-19-854999-7, New York, NY, USA

Wright, S. (1943). Isolation by distance. Genetics, Vol. 28, (November 1942), pp. 114-138, 0975-2862 


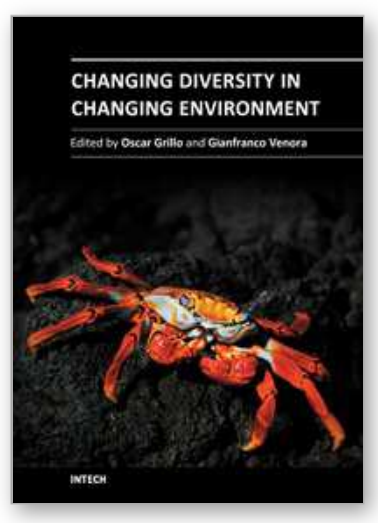

\author{
Changing Diversity in Changing Environment \\ Edited by PhD. Oscar Grillo
}

ISBN 978-953-307-796-3

Hard cover, 392 pages

Publisher InTech

Published online 14, November, 2011

Published in print edition November, 2011

As everybody knows, the dynamic interactions between biotic and abiotic factors, as well as the anthropic ones, considerably affect global climate changes and consequently biology, ecology and distribution of life forms of our planet. These important natural events affect all ecosystems, causing important changes on biodiversity. Systematic and phylogenetic studies, biogeographic distribution analysis and evaluations of diversity richness are focal topics of this book written by international experts, some even considering economical effects and future perspectives on the managing and conservation plans.

\title{
How to reference
}

In order to correctly reference this scholarly work, feel free to copy and paste the following:

Rachel A. Morrison and Stuart A. Sandin (2011). Biogeography and Population Connectivity of Coral Reef Fishes, Changing Diversity in Changing Environment, PhD. Oscar Grillo (Ed.), ISBN: 978-953-307-796-3, InTech, Available from: http://www.intechopen.com/books/changing-diversity-in-changingenvironment/biogeography-and-population-connectivity-of-coral-reef-fishes

\section{INTECH}

open science | open minds

\section{InTech Europe}

University Campus STeP Ri

Slavka Krautzeka 83/A

51000 Rijeka, Croatia

Phone: +385 (51) 770447

Fax: +385 (51) 686166

www.intechopen.com

\section{InTech China}

Unit 405, Office Block, Hotel Equatorial Shanghai

No.65, Yan An Road (West), Shanghai, 200040, China

中国上海市延安西路 65 号上海国际贵都大饭店办公楼 405 单元

Phone: +86-21-62489820

Fax: $+86-21-62489821$ 
(C) 2011 The Author(s). Licensee IntechOpen. This is an open access article distributed under the terms of the Creative Commons Attribution 3.0 License, which permits unrestricted use, distribution, and reproduction in any medium, provided the original work is properly cited. 